\title{
Effectiveness of Mixture of Xylocaine, Bupivacaine and Buprenorphine for Lumbar Blockade by Epidural Approach
}

\author{
Madhavi Mavani ${ }^{1}$, lla Patel ${ }^{2}$ \\ ${ }^{1}$ Assistant Professor, Department of Anaesthesiology, GMERS Medical College \& Civil Hospital, Sola, Ahmedabad, Gujarat, India, ${ }^{2}$ Professor, Department \\ of Anaesthesiology, GMERS Medical College \& Civil Hospital, Sola, Ahmedabad, Gujarat, India.
}

\section{Abstract}

Background: Pain is one of the most compelling experience for human beings. Pain is the most difficult one to define and assess, as it is a purely subjective sensation experienced only by the sufferer. Present study was done in which Buprenorphine was given epidurally along with Bupivacaine and Xylocaine as a single shot technique to evaluate its potency, duration of analgesia and other side effects. Subjects and Methods: Fifty adult patients of ASA risk I/II undergoing lower abdominal surgery, lower limb - orthopaedic surgery, surgery involving perineal region and gynaecological procedures were selected for our study. The patients were divided into two groups consisting of 25 patients each. In group I, patients were given Inj. Bupivacaine $0.5 \% 20 \mathrm{cc}+$ xylacaine in lumbar epidural space. In group II, patients were given Bupivacaine 0.5\% $20 \mathrm{cc}+$ xylacaine $0.5 \% 20 \mathrm{cc}$ mixed with Inj. Buprenorphine $0.2 \mathrm{mg}(2 \mathrm{ml})$ in same syringe in lumbar epidural space. Duration of total analgesia was measured with help of pain scorre, which were measured throughout operative period and in postoperative period. All the statistical tests will be performed in SPSS version 15 software. Results: In study group majority patients complain of pain at around 16 to 20 hours. Most of the patients in group-I are in 0-4 hours and in group - II are 20-24 hours. Maximum respiratory depression was around $12 \%(2 / \mathrm{min})$. It was observed that hypotension was seen in 4 cases and bradycardia in 4 cases - intraoperatively and postoperatively no patient had bradycardia or hypotension in study group. Conclusion: Buprenorphine if given epidurally along with local anesthetic solution for various surgical procedures can provide excellent pain free period lasting up to 24 hours without any disturbances to normal physiology life and notable side effects.

Keywords: Analgesia, Bupivacaine, Hypotension, Pain

Corresponding Author: Dr. Ila Patel, Professor, Dept. of Anaesthesiology, GMERS Medical College \& Civil Hospital, Sola, Ahmedabad, Gujarat, India.

Received: March 2019

Accepted: March 2019

\section{Introduction}

The International Association for the Study of Pain defines pain as "an unpleasant sensory and emotional experience associated with actual or potential tissue damage, or described in terms of such damage". Other than psychological trauma, pain is shown to affect the physiology of almost all the system including respiratory, cardiovascular and metabolic profile there by increasing the morbidity. ${ }^{[1]}$ Pain is one of the most compelling experience for human beings. Pain is the most difficult one to define and assess, as it is a purely subjective sensation experienced only by the sufferer. Pain varies from individual to individual and the type of disease or type or site or surgery. Sharington (1906) in his work on central nervous system has defined pain as "the psychical adjunct to an imperative protective reflex. ${ }^{[2]}$ Pain is the most common and distressing symptom of diseases in medical practice and whatever may be the cause, it demands relief and all medical persons, regard its relief, as one of the their main duties. Pain is a more terrible lord of mankind than death itself. Satisfactory pain relief has always been a difficult problem in clinical practice. ${ }^{[3]}$ It is found that operative pain is more severe after surgery and thereafter gradually diminishes over the next 24 hours. Epidural anesthesia is superior to Spinal and hence is widely being used especially in patients undergoing surgical procedures involving lower parts of the body. To fulfill this demand, there is a need for local anaesthetic with desirable properties like longer duration of sensory blockade and shorter duration of motor blockade. ${ }^{[4]}$

Postoperative pain as being an acute pain, it is often accompanied by changes in autonomic activity. The amount of pain experienced will be proportional to the extent of injury, but the response to pain is influenced by many other factors like previous pain experiences the cultural and social background of the patient, conditioning and suggestion.

The Object of treatment is to provide maximum relief from pan with minimum complications. It is generally agreed that pain following operations is cured inadequately and that current methods of postoperative pain relief as practiced at many places are unsatisfactory because of lack of knowledge about pharmacology of drug or unusual fear of respiratory depression. "Among the remedies which it has please 
almighty God to give to man to relieve his sufferings, none is universal and so efficacious as opium"

Reviewing the various methods, one can still see that administration of opiate remains as a mainstay in the treatment of postoperative pain. With the confirmation of highly specific opiate receptors in the substantiagelatinosa of spinal cord, new possibility manner. i.e. interathecal or epidural injection of opiate derivative for pain relief. A local anesthetic-opioid combination provides superior analgesia during perioperative period.5This combination limits rapid regression of sensory blockade and possibly decreases the dose of local anesthetic administered. Analgesia provided by epidural opioids is superior to that with systemic opioids. Bupivacaine a local anesthetic is widely used drug in epidural anesthesia. Buprenorphine is a thebaine derivative, mu-receptor partial agonist and antagonist. It is effective in relieving moderate to severe pain As it is well known that spinal morphine causes dangerous respiratory depression even quite late search for other opiate derivative continues which does not have this particular side effect. Since the first use of epidural morphine (Behar et al, 1979) 6 number of other opiates have been studied. The search for a suitable alternative to morphine led to the exploration of series $\mathrm{C}$ bridge derivative- Buprenorphine which have agonist antagonist actions. It has high lipid solubility, high affinity for opioid receptors, with slow dissociation from receptors and clinicially prolonged effect with few side effects. This gives pain relief with minimum respiratory depression. Usually it is given at the end of operation through epidural catheter. As it takes some time to have peak effect, sometimes patient experience pain before the drug has its peak effect. ${ }^{[7-9]}$

With the above facts in consideration we have undertaken a study in which Buprenorphine was given epidurally along with Bupivacaine and Xylocaine as a single shot technique to evaluate its potency, duration of analgesia and other side effects.

\section{Subjects and Methods}

\section{Selection of Patients}

Fifty adult patients of ASA risk I/II undergoing lower abdominal surgery, lower limb - orthopaedic surgery, surgery involving perineal region and gynaecological procedures were selected for our study.

Patients were examined thoroughly in the preoperative period and informed consent was taken. Routine and special investigations were done accordingly.

\section{Anaesthetic Management}

The patients were divided into two groups consisting of 25 patients each. In group I, patients were given Inj. Bupivacaine $0.5 \% \quad 20 \mathrm{cc}+$ xylacaine in lumbar epidural space. In group II, patients were given Bupivacaine 0.5\% 20 cc + xylacaine $0.5 \% 20 \mathrm{cc}$ mixed with Inj. Buprenorphine 0.2 $\mathrm{mg}(2 \mathrm{ml})$ in same syringe in lumbar epidural space.

Equipment for procedure

\section{The set prepared for epidural injection was autoclaved.}

1) Sterile tray containing swab-holding forceps and swabs dipped in tincture iodine and spirit solution - to paint local part.

2) One $20 \mathrm{cc}$ and one $5 \mathrm{cc}$ glass syrine.

3) Touhy's needle No.17 with stylet.

4) Hypodermic needle No.24.

5) Spinal towel - for drapping

6) Drugs :

Inj. Xylocaine 2\% - for local infiltration

Inj. Bupivacaine $0.5 \% 20 \mathrm{ml}$ bulb

Inj. Buprenorphine $0.3 \mathrm{mg} / \mathrm{ml}$ - ampoule.

All measures for primary resuscitation were kept ready.

\section{TECHNIQUE}

a) Pre-operative pulse, blood pressure and respiratory rate were checked intravenous line secured, well fixed and fluid therapy started.

b) Patient was placed in lateral decubitus with full-flexion of spine. Both shoulders should be in same vertical plane.

c) After through scrubbing and wearing autoclaved gown and gloves, patient's back was prepared aseptically. Local infiltration with $2 \%$ lignocaine was done in middle of selected lumbar interspace. Then 17 gauze tonhy's needle with stylet inserted through wheal raised, with level pointing cephaled and carefully and slowly advanced until it reaches interspinous ligament. A drop of local anaesthetic was kept at hub of needle after removing stylet so that drop hangs on the hub and needle advanced gently till the drop was sucked in. Confirmation of epidural space was also done by "No resistance test" using saline.

d) In $20 \mathrm{cc}$ syringe, $20 \mathrm{cc}$ of inj. Bupivacaine $0.5 \%$ was taken for group I patients and for group II patients - 0.2 $\mathrm{mg}(2 \mathrm{ml})$ inj. Buprenorphine was added in same syringe. (Commercial preparation of Buprenorphine $0.3 / \mathrm{ml}$ was diluted with saline to make $0.1 \mathrm{mg} / \mathrm{ml}$ ).

e) After aspiration and confirmation of position of touhy's needle in epidural space, above solution was introduced gently.

f) After completion of introduction of drugs, touhy'sneeed was removed immediately with tincture bonzoin seal at site of entry and patient turned to supine position.

g) After recording of vital data (Pulse, blood pressure, respiratory rate) and quality of analgesia. Inj. diazepam $5 \mathrm{mg}$ was given IV slowly and vital data recorded again. Surgery was allowed. Vital data, Pain score, cough score monitored throughout operative period at suitable interval.

h) At the end of surgery, duration of surgery noted. Then every patient kept under observation for atleast 24 hours in post-operative ward. Vital data and degree of analgesia were recorded immediately after completion of surgery and maintained during postoperative period upto 36 hours.

i) Degree of Analgesia assessed by :

Pain score and - cought score

PAIN Score: $\quad 0$ - No Pain

1- $\quad$ Mild pain

2- $\quad$ Moderate pain

Degree of analgesia and side effects itching, Nausea/Vomiting, retention of urine, drowsiness, respiratory 
depression etc. were monitored closely upto 36 hours,

Duration of total analgesia was measured with help of pain score, which were measured throughout operative period and in postoperative period. Duration of total analgesia was considered as a period from epidural blockade to the point when patient feels pain of moderate degree (Pain Score : 2) reflected by demand for some analgesic.

Duration of Postoperative Analgesia was calculated by deducting the duration of surgery from duration of total analgesia. Thus, it is defined as a period between the end point of surgery and the time when patient feels pain of moderate degree (pain score: 2)

Instruction was given in block letter on the care sheet not to give any other analgesic drug without informating me.

\section{Statistical Analysis}

Qualitative data will be expressed as percentages and proportions. Quantitative data will be expressed as mean and standard deviation. All the statistical tests will be performed in SPSS version 15 software. $P$ value $<0.05$ will be considered as statistically significant while $\mathrm{P}$ value $<0.01$ will be considered as statistically highly significant.

\section{Results}

In the present study we have studied 50 patients for intraoperative effects and quality and duration of postoperative analgesia with mixture of Xylocaine bupivacaine and buprenorphine by epidural route.

All the cases included in study were for various surgical procedures. As described earlier they were divided in group I control group and Group - II study group. All the cases were of ASA grade I \& II.

\section{Results obtained were as follows:}

As [Table 1] shows, majority cases in Group I are female and in group II are male. As [Table 2] shows most of the patients studied are in age group above 40 years As [Table 3] shows most of cases in both groups were of abdominal and pelvic surgery.

\section{Pain Scoring \\ $0 \quad$ No Pain \\ $1 \quad$ Mild Pain \\ 2 Moderate Pain}

As Table- 4 shows in control group, in majority of patients pain started at around 4 to 6 hours and at 6 hours out of 25 patients, 24 patients had complain of pain. As Table -5 shows in study group majority patients complain of pain at around 16 to 20 hours. As table shows duration of analgesia in 4-5 hours in group I and 22-23 hours in Group - IIThe duration of total analgesia can be achieved by deducting duration of surgery from duration of total analgesia. As table- 7 shows most of the patients in group-I are in $0-4$ hours and in group - II are 20-24 hours.

In our study by hypotension we mean $20 \%$ our more reduction in blood pressure than basal value and such cases are treated with Inj. Mephetine $0.1 \mathrm{mg} / \mathrm{kg}$. body weight i.v. and oxygen by mask and I.V. fluids. Bradycardia we mean pulse rate below 60/.min such cases were treated with Inj. atropine 0.6 mg. i.v. When respiratory rate falls below $25 \%$ of basal value, it was considered respiratory depression. In our study maximum respiratory depression was around $12 \%$ $(2 / \mathrm{min})$, clinically there was no appreciable fall in tidal volume in any patients. Nausea/ vomiting were treated by Inj. Metoclopramide i.v.

In our study nausea and vomiting were treated by Inj. Metoclopramide i.v. and itching was treated by Inj. Avil. Urinary retention was treated by catheterization.

In patients demanding supplemental analgesia we had given Inj. Ketamine in analgesic doses.

Table 1: Sex Incidence.
\begin{tabular}{|l|l|l|l|}
\hline S.N. & Cases & Group-I & Group - II \\
\hline 01 & Total No. of Cases & 25 & 25 \\
\hline 02 & Male Cases & 12 & 16 \\
\hline 03 & Female Cases & 13 & 9 \\
\hline 04 & $\begin{array}{l}\text { Percentage of Male } \\
\text { Cases }\end{array}$ & 48 & 64 \\
\hline 05 & $\begin{array}{l}\text { Percentage of Female } \\
\text { Cases }\end{array}$ & 52 & 36 \\
\hline
\end{tabular}

\begin{tabular}{l} 
Table 2: Age Incidence \\
\begin{tabular}{|l|l|l|l|}
\hline S.N. & Cases & Group - I & Group - II \\
\hline 1 & Total No. of Cases & 25 & 25 \\
\hline 2 & $\begin{array}{l}\text { Patients Below 20 years } \\
\text { Percentage }\end{array}$ & 0 \\
\hline 3 & $\begin{array}{l}\text { Patients Between age } \\
\text { group }\end{array}$ & 11 & 13 \\
\hline 4 & $21-40$ Years & 44 & 52 \\
\hline & Percentage & 14 & 12 \\
\hline 04 & Patients above 40 years & 56 & 48 \\
\hline & Percentage &
\end{tabular} \\
\hline
\end{tabular}

Table 3: Operative Procedure

\begin{tabular}{|l|l|l|l|l|}
\hline $\begin{array}{l}\text { Operative } \\
\text { Groups }\end{array}$ & $\begin{array}{l}\text { Group } \\
\text { - I }\end{array}$ & $\begin{array}{l}\text { Group } \\
- \text { II }\end{array}$ & $\begin{array}{l}\text { Percentage } \\
\text { of Incidence } \\
\text { in Group -I }\end{array}$ & $\begin{array}{l}\text { Percentage } \\
\text { of Incidence } \\
\text { in Group - } \\
\text { II }\end{array}$ \\
\hline $\begin{array}{l}\text { Gynaecological } \\
\text { surgery }\end{array}$ & 8 & 6 & 32 & 24 \\
\hline $\begin{array}{l}\text { Urological } \\
\text { Surgery }\end{array}$ & 7 & 5 & 28 & 20 \\
\hline $\begin{array}{l}\text { Abdominal and } \\
\text { Pelvic Surgery }\end{array}$ & 10 & 14 & 40 & 56 \\
\hline $\begin{array}{l}\text { Total No. Of } \\
\text { Cases }\end{array}$ & 25 & 25 & 100 & 100 \\
\hline
\end{tabular}

Table 4: Pain Scoring: For Group - I Control Group

\begin{tabular}{|c|c|c|c|c|c|c|c|c|c|c|c|c|c|}
\hline \multicolumn{11}{|c|}{ Duration in Hours } & \multirow{2}{*}{$\begin{array}{l}\text { Duration of Total } \\
\text { Analgeisa }\end{array}$} & \multirow{2}{*}{\multicolumn{2}{|c|}{$\begin{array}{lll}\begin{array}{l}\text { Duration } \\
\text { Analgeisa. }\end{array} & \text { of } & \text { Post-op. } \\
\end{array}$}} \\
\hline No. & 2 & 4 & 6 & 8 & 10 & 12 & 16 & 20 & 24 & 36 & & & \\
\hline 01 & 0 & 1 & 2 & 2 & 2 & 2 & 2 & 2 & 2 & 2 & 4 4'45" & 1'15" & \\
\hline 02 & 0 & 1 & 2 & 2 & 2 & 2 & 2 & 2 & 2 & 2 & $5^{\prime} 15^{\prime \prime}$ & 2'0"' & \\
\hline 03 & 0 & 1 & 2 & 2 & 2 & 2 & 2 & 2 & 2 & 2 & 4'30'” & 1'0"' & \\
\hline 04 & 0 & 1 & 2 & 2 & 2 & 2 & 2 & 2 & 2 & 2 & 4'30'" & 2'0"' & \\
\hline 05 & 0 & 1 & 2 & 2 & 2 & 2 & 2 & 2 & 2 & 2 & $4{ }^{\prime} 45^{\prime \prime}$ & 1'45" & \\
\hline 06 & 0 & 2 & 2 & 2 & 2 & 2 & 2 & 2 & 2 & 2 & 4'0"' & 1'30'" & \\
\hline
\end{tabular}




\section{Mawani d Patel: Lumbar Blackade ly Epidural Approach}

\begin{tabular}{|c|c|c|c|c|c|c|c|c|c|c|c|c|}
\hline 07 & 0 & 1 & 2 & 2 & 2 & 2 & 2 & 2 & 2 & 2 & $5^{\prime} 30^{\prime \prime}$ & 3'30' \\
\hline 08 & 0 & 2 & 2 & 2 & 2 & 2 & 2 & 2 & 2 & 2 & 3'15" & 1'0" \\
\hline 09 & 0 & 0 & 2 & 2 & 2 & 2 & 2 & 2 & 2 & 2 & $50^{\prime \prime}$ & 3'0"' \\
\hline 10 & 0 & 1 & 2 & 2 & 2 & 2 & 2 & 2 & 2 & 2 & 5'30" & 3'45" \\
\hline 11 & 0 & 1 & 2 & 2 & 2 & 2 & 2 & 2 & 2 & 2 & 4'15" & 2'00" \\
\hline 12 & 0 & 2 & 2 & 2 & 2 & 2 & 2 & 2 & 2 & 2 & 3'45" & 1'45" \\
\hline 13 & 0 & 2 & 2 & 2 & 2 & 2 & 2 & 2 & 2 & 2 & 4'0" & 2'0" \\
\hline 14 & 0 & 1 & 2 & 2 & 2 & 2 & 2 & 2 & 2 & 2 & 4'15" & 2'00" \\
\hline 15 & 0 & 2 & 2 & 2 & 2 & 2 & 2 & 2 & 2 & 2 & 3'30'" & 1'45" \\
\hline 16 & 0 & 1 & 2 & 2 & 2 & 2 & 2 & 2 & 2 & 2 & 5'30" & 1'15" \\
\hline 17 & 0 & 1 & 2 & 2 & 2 & 2 & 2 & 2 & 2 & 2 & 4'30' & 2'00" \\
\hline 18 & 0 & 0 & 1 & 2 & 2 & 2 & 2 & 2 & 2 & 2 & 6'30" & 4'00" \\
\hline 19 & 0 & 2 & 2 & 2 & 2 & 2 & 2 & 2 & 2 & 2 & 3'45" & 1'45" \\
\hline 20 & 0 & 1 & 2 & 2 & 2 & 2 & 2 & 2 & 2 & 2 & 4'45" & 2'30" \\
\hline 21 & 0 & 0 & 2 & 2 & 2 & 2 & 2 & 2 & 2 & 2 & 5'30" & 3'00" \\
\hline 22 & 0 & 0 & 2 & 2 & 2 & 2 & 2 & 2 & 2 & 2 & 5'30" & 3'30' \\
\hline 23 & 0 & 2 & 2 & 2 & 2 & 2 & 2 & 2 & 2 & 2 & 4'00" & 1'30" \\
\hline 24 & 0 & 2 & 2 & 2 & 2 & 2 & 2 & 2 & 2 & 2 & 3'45" & 1'45' \\
\hline 25 & 0 & 1 & 2 & 2 & 2 & 2 & 2 & 2 & 2 & 2 & 4'45" & 1'30"' \\
\hline
\end{tabular}

Table 5: Pain Scoring: For Group -II Study Group Duration in Hours

\begin{tabular}{|c|c|c|c|c|c|c|c|c|c|c|c|c|}
\hline & & & & & & & & & & & Analgeisa & Analgeisa. \\
\hline No. & 2 & 4 & 6 & 8 & 10 & 12 & 16 & 20 & 24 & 36 & & \\
\hline 01 & 0 & 0 & 0 & 0 & 0 & 0 & 0 & 1 & 2 & 2 & $24^{\prime} 00^{\prime \prime}$ & $20^{\prime} 30^{\prime \prime}$ \\
\hline 02 & 0 & 0 & 0 & 0 & 0 & 0 & 0 & 0 & 0 & 2 & 32'00', & $30 ' 00$ ', \\
\hline 03 & 0 & 0 & 0 & 0 & 0 & 0 & 0 & 0 & 1 & 2 & 30’00' & 26’30' \\
\hline 04 & 0 & 0 & 0 & 0 & 0 & 0 & 0 & 1 & 2 & 2 & $23^{\prime} 15^{\prime \prime}$ & $21^{\prime} 15^{\prime \prime}$ \\
\hline 05 & 0 & 0 & 0 & 0 & 0 & 0 & 0 & 0 & 1 & 2 & $28^{\prime} 45^{\prime \prime}$ & '"25'00' \\
\hline 06 & 0 & 0 & 0 & 0 & 0 & 0 & 0 & 1 & 2 & 2 & 22'30'” & $20^{\prime} 15^{\prime \prime}$ \\
\hline 07 & 0 & 0 & 0 & 0 & 0 & 0 & 0 & 1 & 2 & 2 & 23'30' & $21^{\prime} 45^{\prime \prime}$ \\
\hline 09 & 0 & 0 & 0 & 0 & 0 & 0 & 0 & 1 & 2 & 2 & $20^{\prime} 45^{\prime \prime}$ & $18^{\prime} 30^{\prime \prime}$ \\
\hline 10 & 0 & 0 & 0 & 0 & 0 & 0 & 1 & 2 & 2 & 2 & 16'30' & 14'00'” \\
\hline 11 & 0 & 0 & 0 & 0 & 0 & 0 & 0 & 1 & 2 & 2 & $20^{\prime} 30^{\prime \prime}$ & 19’00' \\
\hline 12 & 0 & 0 & 0 & 0 & 0 & 0 & 0 & 2 & 2 & 2 & $17^{\prime} 30^{\prime \prime}$ & $15^{\prime} 00^{\prime \prime}$ \\
\hline 13 & 0 & 0 & 0 & 0 & 0 & 0 & 0 & 1 & 2 & 2 & 20’30'’' & 18'30'’ \\
\hline 14 & 0 & 0 & 0 & 0 & 0 & 0 & 0 & 0 & 1 & 2 & $25^{\prime} 30^{\prime \prime}$ & $23^{\prime} 30^{\prime \prime}$ \\
\hline 15 & 0 & 0 & 0 & 0 & 0 & 0 & 0 & 0 & 1 & 2 & $26^{\prime} 30^{\prime \prime}$ & $24^{\prime} 00^{\prime \prime}$ \\
\hline 16 & 0 & 0 & 0 & 0 & 0 & 0 & 0 & 1 & 2 & 2 & $21^{\prime} 45^{\prime \prime}$ & $17^{\prime} 45^{\prime \prime}$ \\
\hline 18 & 0 & 0 & 0 & 0 & 0 & 0 & 0 & 1 & 2 & 2 & $23^{\prime} 45^{\prime \prime}$ & $21^{\prime} 45^{\prime \prime}$ \\
\hline 19 & 0 & 0 & 0 & 0 & 0 & 0 & 0 & 1 & 2 & 2 & $22^{\prime} 15^{\prime \prime}$ & $20 ' 00^{\prime \prime}$ \\
\hline 20 & 0 & 0 & 0 & 0 & 0 & 0 & 0 & 1 & 2 & 2 & 22'30' & $19^{\prime} 45^{\prime \prime}$ \\
\hline 21 & 0 & 0 & 0 & 0 & 0 & 0 & 1 & 2 & 2 & 2 & $16^{\prime} 15^{\prime \prime}$ & $133^{\prime} 45^{\prime \prime}$ \\
\hline 22 & 0 & 0 & 0 & 0 & 0 & 0 & 1 & 2 & 2 & 2 & $19^{\prime} 15^{\prime \prime}$ & 16'30'” \\
\hline 23 & 0 & 0 & 0 & 0 & 0 & 0 & 0 & 1 & 2 & 2 & $20^{\prime} 30^{\prime \prime}$ & $18^{\prime} 45^{\prime \prime}$ \\
\hline 24 & 0 & 0 & 0 & 0 & 0 & 0 & 0 & 1 & 2 & 2 & 22'00'” & $200^{\prime} 00^{\prime \prime}$ \\
\hline 25 & 0 & 0 & 0 & 0 & 0 & 0 & 0 & 2 & 2 & 2 & $23 ' 30$ '” & $21^{\prime} 45^{\prime \prime}$ \\
\hline
\end{tabular}

Table 6: Duration of Total Analgeisa

\begin{tabular}{|l|l|l|}
\hline $\begin{array}{l}\text { Duration on } \\
\text { analgesia in hours }\end{array}$ & $\begin{array}{l}\text { No. of Patients in } \\
\text { Group - I }\end{array}$ & $\begin{array}{l}\text { No. Of Patients in } \\
\text { Group - II }\end{array}$ \\
\hline 0 to 4 hours & 8 & 0 \\
\hline 4 to 8 hours & 17 & 0 \\
\hline 8 to 12 hours & 0 & 0 \\
\hline 12 to 16 hours & 0 & 0 \\
\hline 16 to 20 hours & 0 & 5 \\
\hline 20 to 24 hours & 0 & 15 \\
\hline 24 to 36 hours & 0 & 5 \\
\hline Mean duration of & 4 hours and & 22 hours and \\
\hline of total analgesia & 36 minutes & 42 minuts \\
\hline & SD+ 46.29 min. & SD +224.8 min \\
\hline
\end{tabular}

Table 7: Duration of Post - Opeative Analgesia

\begin{tabular}{|l|l|l|}
\hline $\begin{array}{l}\text { Duration of analgesia } \\
\text { in hours }\end{array}$ & $\begin{array}{l}\text { No. of Patients in } \\
\text { Group - I }\end{array}$ & $\begin{array}{l}\text { No. Of Patients in } \\
\text { Group - II }\end{array}$ \\
\hline 0 to 4 hours & 25 & 0 \\
\hline 4 to 8 hours & 0 & 0 \\
\hline 8 to 12 hours & 0 & 0 \\
\hline 12 to 16 hours & 0 & 3 \\
\hline 16 to 20 hours & 0 & 9 \\
\hline 20 to 24 hours & 0 & 10 \\
\hline
\end{tabular}

24 to 36 hours

Mean duration of

0

20'22"

\begin{tabular}{lll}
\hline Prosoperative Analgesia & $\mathrm{SD}+50.31 \mathrm{~min}$. \\
\hline
\end{tabular}

$\mathrm{SD}+217.3 \mathrm{~min}$.

\section{Table 8: Intraoperative Complications}

\begin{tabular}{|l|l|l|}
\hline & Group- I & Group- II \\
\hline Nausea/ Vomiting & $2(8 \%)$ & $2(8 \%)$ \\
\hline Hypotension & $4(16 \%)$ & $4(16 \%)$ \\
\hline Bradycardia & $3(12 \%)$ & $4(16 \%)$ \\
\hline Respiratory depression & 0 & 0 \\
\hline
\end{tabular}

\section{Table 9: Postoperative Complications}

\begin{tabular}{|l|l|l|}
\hline & Group- I & Group -II \\
\hline Nausea/ Vomiting & 4 & 4 \\
\hline Drowsiness & 2 & 4 \\
\hline Urinary Retention & 2 & 3 \\
\hline Itching & 0 & 1 \\
\hline
\end{tabular}

\section{Discussion}

Postoperative pain-relief is gaining considerable attention in recent years, particularly after the discovery of opiate 
analgesics and their use by various routes. Since last 2-3 decades patients are also becoming aware of the postoperative pain relief and are demanding for same, with minimal disturbances to their physiological life. Pain free condition for frist few postoperative hours makes patient comfortable. ${ }^{[10]}$

To achieve best results, anaesthesiologist should choose drug which have logner duration of action, more profound analgesia, good sedative effect and less side effects. We should use such drugh in minimum adequate dose and should be given by such route that patients are not frequently disturbed. Ideal opioid for extradural use should have high lipid solubility, high molecular weight, strong binding capacity to receptor, intese and prolonged intrinsic activity and few side effects. Morphine was used since long and search for an alternative agent to it lead to the use of Buprenorphine- thebaine derivative for postoperative pain relief. Buprenorphine satisfied most of the above criteria and can be considered as a near ideal opioid drug. ${ }^{[11,12]}$

In the present study of 50 cases planned for various major surgical procedures, we have studied efficacy of Buprenorphine for providing post-operative analgesia when given by extradural route along with Bupivacaine $0.5 \%$ as a single shot technique. Owing to different site of action of both these drugs, no interaction was observed in the effectiveness of each when both were used together.

In the present study, none of analgesic drug as a part of premedication or intraoperative medication was used to prevent interference with assessment of analgesic activity of Buprenorphine. To all patients, during preoperative visit, full explanation of procedure and reassurance was given instead of pharmacological premedication. Allen Dobkkin (1980)13in his study premedicated all patients with Inj. atropine and diazepam only. gudy (1987)11 used sup. antacid and $10 \mathrm{mg}$. diazepam orally one hr. before operation.

In the present study we have used inj. Buprenorphine $0.2 \mathrm{mg}$. $(=2 \mathrm{ml})$. For effective analgesia by extgradural route, doses of opiate same as systemic must be used, because the extradural opiate act more or less like an IM opiate but with prolonged action (RES bullingham et al). ${ }^{[14]}$

The onset of action of epidural buprenorphine is found to be about $15 \mathrm{~min}$. with maximum effect at $30 \mathrm{~min}$ (Rondomanska, 1982), ${ }^{[15]}$ if given at the end of operation patient may have a painful part of period till the drug start its action. To prevent this Buprenorphine was given along with local analgesic drug to have continuous pain free period form beginning of surgery.

Many observers have observed comparatively prolonged duration of postoperative analgesia by using Buprenorphine epidurally. Cahill et al (1983), ${ }^{[16]}$ observed comparatively long duration of pain relief with a small dose of 60 ugm Buprenorphine epidurally. J.L. Graham et al (1980), ${ }^{[17]}$ used morphine $2 \mathrm{mg}$ epidurally and achieved postoperative pain free period over $12 \mathrm{hrs}$. with excellent quality of analgesia. He compared its effectiveness with Bupivacaine and observed morphine superior to Bupivacaine in quality and total duration of analgesia. T.A. Torda (1981), ${ }^{[18]}$ administered morphine epidurally for postoperartive analgesia and achieved good analgesia in most of patients with duration ranged from 6 hours up. Lanz et al (1984), ${ }^{[19]}$ observed that with $0.15 \mathrm{mg}$. Buprenorphine, men duration of analgesia was 6 hrs., while with $0.3 \mathrm{mg}$, it was about $12 \mathrm{hrs}$. S. Chakraborty (1984) ${ }^{[8]}$ used $0.3 \mathrm{mg}$. Buprenorphine by epidural route and found analgesia upto $20 \mathrm{hrs}$. Rondomanska (1982), ${ }^{[15]}$ used $0.3 \mathrm{mg}$. Buprenorphine and got painfree period for about 24 hours. Gudy A.R. (1987), ${ }^{[20]}$ reported that increasing the dose of Buprenorphine to $0.6 \mathrm{mg}$ did not produce proportionate increase in analgesia but increasing chances of side effects, particualry respiratory depression. The findings observed by these observers are confirmed by present study. In present study we have achieved an average postoperative analgesia 20'22" hrs. With $0.2 \mathrm{mg}$. Buprenorphine given epidurally. In our study we have measured duration of analgesia with help of pain score and cough score. Upto 12 hours, total postoperative pain score is only " 0 ", ' 5 ' at $16 \mathrm{hrs}$. and then increases gradually upto ' 50 ' at 36 hours period. Cough score was decreasing from ' 50 ' at 2 hours to ' 43 ' at 36 hours in Group II. These results are comparable to results obtained by A. Shakoor et al (1990), ${ }^{[21]}$

In our study, characteristic of Buprenorphine were evaluated when administered by epidural route for postoperative analgesia. There are more studies using Buprenorphine by different routes other than epidural and also comparison with other narcotics when given by same route or other route. Allen Dobkin (1977), ${ }^{[13]}$ Compared Buprenorphine 0.2.-0.4 $\mathrm{mg}$. IM with morphine 5-10 mg. by same route. Duration of pain relief was substantially longer with Buprenorphine. A Rudra (1985), ${ }^{[12]}$ compared epidural Buprenorphine $0.5 \mathrm{mg}$ with epidural morphine $7.5 \mathrm{mg}$. Analgesia was of much longer duration with former B.C. Howell (1977), ${ }^{[22]}$ compared Buprenorphine $4-8 \mathrm{ug} / \mathrm{kg}$. IM with pethidine 1 $\mathrm{mg} / \mathrm{kg}$ and pentazocine $0.6 \mathrm{mg} . / \mathrm{kg}$. IM Analgesia was better with Buprenorphine than pethidine and pentazocine. $\mathrm{M}$. Freedman (1986)23 compared Buprenorphine (0.5 mg. and $0.6 \mathrm{mg}$ ) with pentazocine $(30 \mathrm{mg}$ and $60 \mathrm{mg}$ ) He observed that Buprenorphine $0.3 \mathrm{mg}$. provide better pain relief than pentazocine $60 \mathrm{mg}$ at 3 and 6 hours. These above studies also showed that Buprenorphine provided excellent analgesia or prolonged duration than other opiates administered by various routes.

After administration of drug, vital data like Pulse, Blood Pressure, Respiratory rate recorded frequently infraoperatrively and postoperatively to evaluate effects of drug on cardiovasetlar and respiratory system. Study by Allen Dobkin (1977), ${ }^{[13]}$ S. Chakraborty $(1984),{ }^{[8]}$ A. Rudra (1985), ${ }^{[12]}$ Harcus A.H. (1980), ${ }^{[24]}$ T.A. torda $(1981),{ }^{[25]}$ have shown Buprenorphine were remarkably free from any significant cardiovascular insults attributable to this drug from our study, we also confirm the same, we ahave considered bradycardia when pulse rate was less then $60 /$ min. and hypotension when reduction in blood pressure was more $20 \%$ of basal level and we had found hypotension in 4 cases and bradycardia in 4 cases - intraoperatively and postoperatively no patient had bradycardia or hypotension in study group. Bradycardia and/or hypotension intraoperatively may be due to sympathetic blockade produced by local anaesthetic solution as none of patient in our study had cardiovascular instability postoperatively.

None of the patient in present study had respiratory depression. We have considered respiratory depression when reduction in respiratory rate was more than $25 \%$ of basal 
respiratory rate. No cyanosis or abnormal ventilator pattern were detected in either group. A Dobkin (1977), ${ }^{[13]}$ and Harcus A.H. (1980), ${ }^{[24]}$ who had used Buprenorphine by IM route, observed no appreciable respiratory depression. S. Chakkaraborty (1984), ${ }^{[8]}$ used epidural Buprenorphine 0.3 $\mathrm{mg}$ in his study and failed to observe any signinficnat change in respiratory rate and tidal volume A. Rudra (1985), ${ }^{[12]}$ and a. Shakoor (1990), ${ }^{[21]}$ also used Buprenorphine $0.3 \mathrm{mg}$ epidurally and got same result and supports our observation.

Other most common side effect of Buprenorphine reported were nausea/ vomiting, urinary retention and sedation. In our study, incidence of nausea/ vomiting is in 2 cases intraoperatively and 4 cases postoperatively in either group. Study of A. Rudra (1985), ${ }^{[12]}$ A. Shakoor $(1990)^{[21]}$ S. chakraborty (1984)8 supports rthis observation. In present study urinary retention was observed in 3 cases $(12 \%)$ in group II, while in 2 cases (85) in group I, in non catheterized patents. A. Rudra $(1985)^{[12]}$ and A. Shakoor (1990) ${ }^{[21]}$ also used Buprenorphine $0.3 \mathrm{mg}$ epidurally and got same results and supports our observation.

Other most common side effects of Buprenorphine reported were nausea/ vomiting, urinary retention and sedation. In our study, incidence of nausea/ vomiting is in 2 cases intraoperatively and 4 cases postoperatively in either group. Study of A. Rudra (1985), ${ }^{[12]}$ A shakoor (1990), ${ }^{[1]} \mathrm{S}$. Chakraborty (1984), ${ }^{[8]}$ supports this observation. In present study urinary retention was observed in 3 cases $(12 \%)$ in group II, while in 2 cases (85) in group. I in non-catheterized patents. A Rudra (1985), ${ }^{[12]}$ found $20 \%$ incidence of urinary retention with epidural Buprenorphine. A Shakoor (1984), ${ }^{[21]}$ found $5 \%$ incidence. Our result matches with that of above studies.

Study conducted by us shows drowsiness in $16 \%$ (4 cases) of patients of group II. Although the patients were drowsy, they were easily arousable. A Dobkin (1977), ${ }^{[13]}$ found in his study of Buprenorphine IM-drowsiness was the only frequent side effect A Rudra (1984), ${ }^{[12]}$ found drowsiness in $12 \%$ of patients in his study. Gudy $(1987),{ }^{[20]}$ in his study found drowsiness as a common side effect in all his patients.

The observed drowsiness can be explained on the basis of agonistic action for K-receptors. In our study itching was observed in $4 \%$ of patients in study group. It was mainly confined to area around nose and usually does not require any treatment. A. Shakoor (1990), ${ }^{[21]}$ observed itching as a side effect in $5 \%$ of studied patients. Facial itch occasionally seen with parenteral opiate was explained by action of opiate on spinal trigeminal nucleus. (RES Bullingham et al). ${ }^{[14]}$

Thus our present study of Buprenorphine when administered epidurally with local anaesthetic solution - Bupivacaine before operation, as a single shot technique provides excellent analgesia for prolonged period with minimal side effects. Advantage of present study is that the single prick is lumbar region will provide post- operative analgesia with complete anaesthesia for the particular operation. The patient acceptance of this technique was very high. Most of the patients in the study group were fully satisfied with postoperative pain relief and expressed the willingness to undergo the same technique again, if surgery is needed in future, showing the excellent analgesic effect of Buprenorphine epidurally.

\section{Conclusion}

From above study it was concluded that Buprenorphine is very good drug for postoperative pain relief. Quality of analgesia is excellent by epidural route and by missing it with local anesthetic solution, as a single injection, we can avoid repeated injection. Buprenorphine when given epidurally leaves the ability to cough intact and thus there is less incidences of lung stasis and respiratory complications postoperatively. Cardiovascular stability is confirmed, when drug is given epidurally. It does not cause respiratory depression when used in dose of $0.2 \mathrm{mg}$. epidurally. Systemic analgesic injections are not required in the postoperative period if epidural Buprenorphine is used for pain relief. Side effects like urinary retention, drowsiness, nausea, vomiting, itching are reported but they are not much distressing. So, Buprenorphine if given epidurally along with local anaesthetic solution for various surgical procedures can provide excellent pain free period lasting up to 24 hours without any disturbances to normal physiology life and notable side effects.

\section{References}

1. Dr.Nirvik Pal, Dr.Kiran Malhotra, Dr.Chitra et al. Effect of morphine on postoperative respiratory functions: Comparision between systemic and epidural routes. Indian J. Anaesth 2004;48(3):204-207.

2. Bullingham RES, waston P.J.Q. McQuay H.J. : Single dose comparison of Buprenorphine $0.3 \mathrm{mg}$ and $0.6 \mathrm{mg}$ IV given after operation : Clinical effects and plasma concentration. Br. Jr. Anesthesia 1982: 54: 37-43.

3. RG Wheatley, SA Schug, D. Watson. Combination of local anaesthetic and an opioid combination. Br J Anaesth 2001;87:47.

4. Zenz M., Pipen brock S., Hubner B., Glocke M: „A double blind comparison of epidural Buprenorphine and epidural morphine in postoperative pain ${ }^{e c}$. Anaesth - Intensive therapy - Notfallmed 1981; 16(6): 333-9.

5. SurajDhale, VaishaliShelgaonkar and VV Akulwar. A comparative study of epidural bupivacaine and epidural bupivacaine with fentanyl for peri operative analgesia. Indian journal anaesthesia 2000;44:35.

6. Behar M. : Epidural morphine in treatment of pain : Lancet1979 : 1 527-8:

7. H.J. McQuay, RES Bullingham, G.M.C. Paterosn and R.A. Mooore clinical effects of Buprenokrphine during and after surgery : Br. Jr. Anaesthesia $1980: 52$ : 1013-19.

8. S.Chakraborty, d. Banerjee, GobindaSaha : Buprenorphine in epidural analgesia for post operative pain : Ind. Jr. Anaesthsia 1984 : June : 32 : $3: 243-46$.

9. gustafsson L.L., Schildt B, Jacobson K. : Adverse effects of extradural and intrahecal opiates : Br. Jr. Anaesthesia 1982 : 54: 479-86.

10. A.H.B. Masson : the role of analgesic drugs in the treatment of postoperative pain : Br. Jr. Anaesthesia 1967: 39: 713.

11. A.K. Unnikrishnan : Epidural morphine for postoperative analgesia A clinical evaluation Ind. Jr. Anaestheisa 1983 : 31: 5: 330.

12. A. Rudra, Mazmudar ; Postoperative analgesia with single injection epidural Buprenorphine and morphine mixed with lignocaineadrenaline Ind. Jr. Anaesthesia $1985: 33: 3: 43-45$.

13. Allen B. Dobnkin, Barbara Esposito and Carole Philbin : Double blind evaluation of Buprenorphine hydrochloride for postoperative pain : CanedianAnaesth. Soc. Jr 199724 : 2: 195-201.

14. R.E.S. Bullingham ,H.J.McQuay, R.A. Moore : Extradural and intradural narcotics : Recent advances in Anaesthesiaasnd analgesia $198214: 141$

15. Rondomanska M., d' Castro J. Larcon L. : The use of epidural Buprenorphine for treatment of postoperative pain : Anaesthesiology and intensive care medicine $1982: 144: 91-4$.

16. Dobkkin A.B. : Determination of analgesic potency : Buprenorphine, pethidine and pentazocine for relief of pain after operation : CanedianAnaesth. Soc. Jr 1977. : 24 : 186. 
17. J.L. graham, r. King, W. McCaughey : Postoperative pain relief using epidurtal morphine : anaesthesia $1980: 35: 158-60$.

18. T.A.Torda, D.A. Pybus : Clinical experience with Epidural Morphine : Anaesth. Intensive Care : $9: 129: 1981$.

19. Lanz E. simko G., TheissD : Epidural Buprenorphine : A double blind study of postoperative analgesia and side effects. Anaesthesia and analgesia : $63: 593-8: 1984$.

20. Gudy A.R. : Single shot epidural lignocaine and Buprenorphine for postoperative pain relief. Ind. Jr. Anaesthesia : $35:(1): 52: 1987$.

21. A Shkoor, Mittal A ; S.W.A. Sabzposh, Swaraj : Postoperative pain relief by Buprenorphine given with local analgesic solution for epidural anaesthesia: Ind. Jr. Anaesthesia : 38: 2: 1990.

22. B.C.Hovell : Comparison of Buprenorphine, Pethidine and Pentazocine for postoperative pain relief after operation : Br. Jr. Anaesthesia : $49: 913-916: 1977$.

23. M. Freedman : A comparison of Buprenorphine and pentazocine for pain relief of postoperative pain : SAMJ : $69: 27-29: 1986$.

24. Harcus A.H. : Buprenorphine in postoperative pain relief using epidurtal morphine : anaesthesia : 35: 158-60: 1980.

25. T.A.Torda, D.A. Pybus : Clinical experience with Epidural Morphine : Anaesth. Intensive Care : $9: 129: 1981-84$.

Copyright: () the author(s), publisher. Academia Anesthesiologica International is an Official Publication of "Society for Health Care \& Research Development". It is an open-access article distributed under the terms of the Creative Commons Attribution Non-Commercial License, which permits unrestricted non-commercial use, distribution, and reproduction in any medium, provided the original work is properly cited.

How to cite this article: Gandhi R, Shah A, Patel I. Effect of Age and Gender on Incidence of Post Spinal Headache. Acad. Anesthesiol. Int. 2019;4(1):42-48.

DOI: dx.doi.org/10.21276/aan.2019.4.1.10

Source of Support: Nil, Conflict of Interest: None declared. 